\title{
Growth and Haematological Response of Clarias gariepinus to Garlic (Allium sativum) Supplemented Diet
}

\author{
Abigail John Onomu ${ }^{1}$ \\ ${ }^{1}$ Department of Zoology and Entomology, University of Fort Hare, Alice, P.B x1314, Eastern Cape, 5700, South \\ Africa \\ Correspondence: Abigail John Onomu, Department of Zoology and Entomology, University of Fort Hare, Alice, \\ P.B x1314, Eastern Cape, 5700, South Africa. E-mail: abigailjohn90@gmail.com
}

Received: November 12, 2018 Accepted: November 30, 2018 Online Published: December 26, 2018

doi:10.5539/sar.v8n1p67

URL: https://doi.org/10.5539/sar.v8n1p67

\begin{abstract}
This study investigated the growth and haematological response of Clarias gariepinus to different concentration of garlic supplemented diet for a period of 12 weeks. This study was carried out in 2011 in the premises of Fisheries Department, Delta State University, Asaba, Nigeria. The experimental diet was formulated to contain 0\% (control), $0.5 \%, 1 \%$ and 3\% garlic. Fish were sorted into four groups based on the diet and were fed 3\% live body weight. Diets which contain garlic did not show a significant effect $(P=0.06)$ on the weight of $C$. gariepinus. However, fish fed diets containing garlic had a higher $(P<0.001)$ total length compared to the control. Nevertheless, fingerlings fed $0.5 \%$ concentration of garlic in diet exhibited greater growth in terms of weight and length compared to fingerlings in all other treatment groups and the control. At the end of the experiment, the total red blood cell count (RBC), white blood cell count (WBC), haemoglobin ( $\mathrm{Hb}$ ) and packed cell volume $(\mathrm{PCV})$ of fish in the garlic supplemented groups were greater $(P<0.05)$ compared to the values prior to the commencement of the experiment and to the control. However, catfish fed $0.5 \%$ garlic diet were observed to have a higher value of RBC, PCV and $\mathrm{Hb}$ than the other concentrations. Increment in plasma protein was noted in catfish fed garlic supplemented diet than the control.

This study demonstrates that garlic supplemented feed stimulates increment in both total length and haematological indices of fish. Supplementation of fish feed with garlic is therefore of high benefit in aquaculture as it boosts the ability of $C$. gariepinus to resist diseases.
\end{abstract}

Keywords: blood parameters, catfish (Clarias gariepinus), garlic supplemented diet

\section{Introduction}

Disease is a limiting factor and a major threat to aquaculture as it is one of the major causes of mass mortalities (Lee \& Gao, 2012; Yunxia, Jianzhong, \& Guoliang, 2001). In order to prevent disease in aquaculture, immunostimulant has been used (Subasinghe, 1997). The utilisation of immunostimulant in aquaculture has become a habitual procedure in fish farming because they improve the functioning of non - specific defence system and provide defence against diseases (Shalaby, Khattab, \& Abdel Rahman, 2006). However, most immunostimulants and various substances that possess the ability to act as immunostimulants are not appropriate for application in aquaculture (Ahmadifar, Azari, \& Sudagar, 2009). This is due to the fact that they not only pollute the environment but also results in drug residue in the animal which could be harmful if consumed by humans (FAO/WHO/OIE, 2006). Also, the application of antibiotics, antimicrobials and disinfectant for relatively long periods has led to pathogen resistance in treated fish. More so, the high price associated with purchasing immunostimulant makes it uneconomical for fish farming (Raa, Rodstand, Engstad, \& Robertson, 1992).

Garlic has been critically examined over the years and has been reported to exhibit antibacterial properties, improve the well- being of fish and check pathogens like bacteria and fungi (Harris, Cottrell, Plummer, \& Lloyd, 2001). Garlic is one of the several plants that is being used in traditional medicines and has a broad range of actions which does not include only antiviral, antibacterial, antiprotozoal and antifungal likewise beneficial on the immune and cardiovascular systems (Fazlolahzadeh, Keramati, Nazifi, Shirian, \& Sefi, 2011). Garlic is made of various organosulfur compounds such as allicin, ajoene, S-allylcysteine, diallyldisulfide, S-methylcysteine 
sulfoxide and S-allyl cysteine (Corzomartinez, Corzo, \& Villamiel, 2007).

Growth improvement has been observed in fish fed with garlic supplemented (Dias, El-Nagar, \& El-Hady, 2002; Metwally, 2009; Nya \& Austin, 2009). Allicin has been reported as the compound responsible for growth enhancement and is able to attain this by improving intestinal flora and digestion, thereby leading to an increased growth rate (Lee \& Gao, 2012). Improved haematological parameter has been reported for fish fed with garlic supplemented diet. Hence this study seeks to investigate the growth and haematological response of Clarias gariepinus to garlic supplemented diet. We hypothesized that Clarias gariepinus will show improved growth and haematology in response to garlic inclusion in diet.

\section{Materials and Methods}

\subsection{Study Area}

The study was carried out in 2011 in the premises of Fisheries, Delta State University, Asaba, Delta State, Nigeria.

\subsection{Duration of the Study}

The study was carried out for a duration of 12 weeks.

\subsection{Samples Collection}

Four weeks old of Clarias gariepinus were bought from a farm in Asaba, Delta State, Nigeria and the fresh garlic used in the study was purchased from a market in Asaba.

\subsection{Preparation of garlic powder}

The skin of garlic cloves was removed then sun-dried. The the cloves were crushed to powder.

\subsection{Experimental Diet}

Four experimental diets with different quantity of garlic were formulated. The diets are $0 \%$ (control); $0.5 \% ; 1 \%$ and 3\% garlic. The feed was formulated from locally available ingredient (Table 1), which were granulated and pelleted with a manually operated pelletiser. Thereafter the pellets were oven-dried at $60^{\circ} \mathrm{C}$ for 24 hours. Proximate analysis of the diet was done according to procedures of the Association of Official Analytical Chemist (1984). Crude protein was analysed by the Kjeldahl method; crude lipid was estimated with a Soxhlet apparatus [chloroform - methanol (2:1, v/v) extraction method; crude fiber was determined by fibretec system M1020 hot extractor (Foss Tecator); ash and moisture content was detected with a muffle furnace at $505^{\circ} \mathrm{C}$ and oven at $105^{\circ} \mathrm{C}$ respectively.

Table 1. Composition of experimental diets

\begin{tabular}{lllll}
\hline Feed ingredients & 0\% garlic & 0.5\% garlic & 1\% garlic & 3\% garlic \\
\hline Fish meal & 25.55 & 25.55 & 25.55 & 25.55 \\
Groundnut cake & 14.43 & 14.43 & 14.43 & 14.43 \\
Soya bean meal & 17.30 & 17.30 & 17.30 & 17.30 \\
Wheat bran & 33.51 & 33.01 & 32.51 & 30.51 \\
Garlic & 0.00 & 0.50 & 1.00 & 3.00 \\
Oil & 2.25 & 2.25 & 2.25 & 2.25 \\
Salt & 1.00 & 1.00 & 1.00 & 1.00 \\
Methionine & 0.50 & 0.50 & 0.50 & 0.50 \\
Lysine & 0.50 & 0.50 & 0.50 & 0.50 \\
Vitamin C & 0.50 & 0.50 & 0.50 & 0.50 \\
Bone meal & 2.46 & 2.46 & 2.46 & 2.46 \\
Starch & 2.00 & 2.00 & 2.00 & 2.00 \\
\hline
\end{tabular}

Table 2. Proximate analysis of the experimental diets

\begin{tabular}{lllll}
\hline & 0\% garlic & $0.5 \%$ garlic & $1 \%$ garlic & $3 \%$ garlic \\
\hline Moisture & 9.07 & 9.01 & 9.50 & 9.75 \\
Crude protein & 43.50 & 42.50 & 42.25 & 43.75 \\
Crude lipid & 6.50 & 6.15 & 6.34 & 6.20 \\
Crude fiber & 11.80 & 11.70 & 10.35 & 9.70 \\
Ash & 12.30 & 11.00 & 11.65 & 12.50 \\
\hline
\end{tabular}




\subsection{Experimental Design}

Fingerlings were acclimatized in tanks for a period of two weeks so as to enable them to adjust to the environment. The tanks were well aerated and water was maintained at a temperature of $25^{\circ} \mathrm{C}$. Fishes were stocked into four tanks (according to the diet type) at a stocking density of 15 fish per tank. Each of the tanks had three replicates. Fishes were fed at 3\% live body weight twice daily (8:00 a.m. and 6:00 p.m.). The feeding rate was readjusted as fishes increased in weight.

\subsection{Growth}

This was done in terms of weight $(\mathrm{g})$ and in total length $(\mathrm{cm})$ Fish growth was evaluated weekly.

The percentage weight gain was calculated as:

Weight gain $(\%)=100$ (Final Body Weight - Initial Body Weight).

\subsection{Collection of Blood Sample}

Blood samples were collected from the caudal vein of fish before the commencement of the experiment and weekly during the study with the aid of a syringe. Blood samples were instantly placed into an EDTA bottle to keep blood from clotting. Blood was estimated for total white blood cells (WBC) count, red blood cells (RBC) counts, pack cell volume (PCV), haemoglobin $(\mathrm{Hb})$ and plasma protein. Total WBC and RBC counts were estimated with the Neubauer haemocytometer. PCV was analysed using a microhaematocrit centrifuge for 10 minutes at $1200 \mathrm{pm}$ and the result was read using a microhematocrit reader. $\mathrm{Hb}$ was analysed by the Cyamethaemoglobin method and plasma protein with the aid of a refractometer.

\subsection{Analysis of Data}

Data passed the test for homogeneity of variance (Levene's test) and normality of distribution (Kolmogorov-Smirnov test). A one- way analysis of variance (ANOVA) was used to test for the effect of garlic supplemented feed on growth and also on haematological parameters. Where a significant result is found $(\mathrm{p}<0.05)$, the Tukey test was used for all post-hoc multiple comparisons to analyse for significant difference among treatments

\section{Results}

At the end of the experiment, the weight of $C$. gariepinus in all the treatment groups increased from the initial weight. Fish in the $0.5 \%$ treatment group had a higher weight gain, which was however not different (ANOVA: $\mathrm{F}=2.65, P=0.06$ ) from those fed on $0 \%$ (control); $1 \%$ and 3\% diets (Figure 1A). The total length of $C$. gariepinus in $0.5 \%$ group was greater (ANOVA: $\mathrm{F}=19.1, P<0.001$ ) than those in the control group and those in $1 \%$ and $3 \%$ garlic supplemented group (figure $1 \mathrm{~B}$ ).

The WBC counts of fish fed various levels of garlic supplemented garlic showed continuous weekly increase unlike those of the control group (0\%) which was virtually constant all through the study (Figure 2). Of the fishes fed the various garlic supplemented diets, the $0.5 \%$ concentration had higher (ANOVA: F= 774, $P<$ $0.0001)$ WBC counts. 


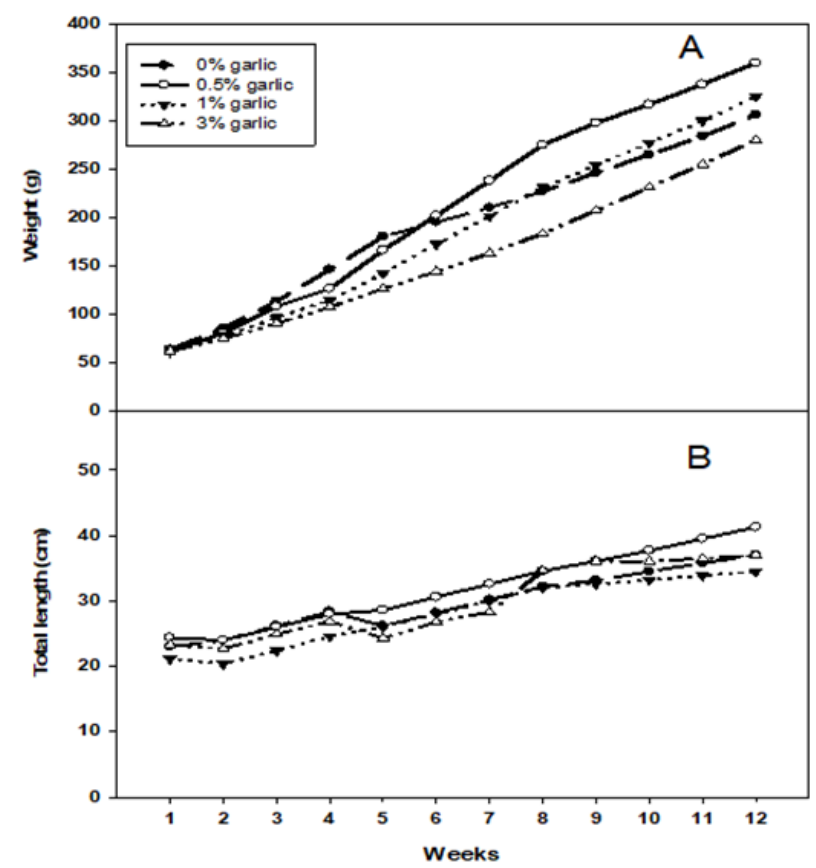

Figure 1. (A) Mean weight (B) Mean total length of Clarias gariepinus which fed on four levels of garlic supplemented diet over 12 weeks period

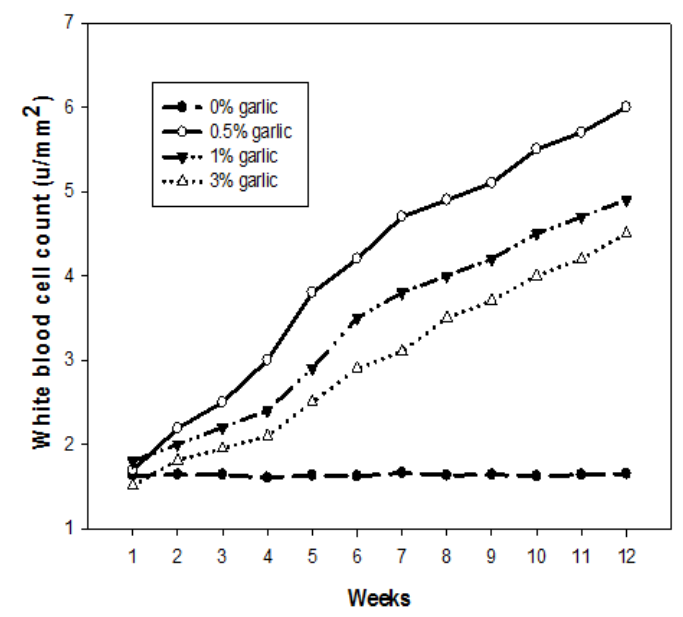

Figure 2. Mean white blood cell count $\times 10^{12}$ of Clarias gariepinus which fed four on levels of garlic supplemented diet over 12 weeks period

Similarly, the final RBC count of the garlic supplemented treatment groups was higher (ANOVA: $F=1298$, $\mathrm{p}<0.0001)$ than those fed garlic-free diet (control group). However, among the garlic supplemented groups, fish in $0.5 \%$ garlic diet had higher $(P<0.05)$ RBC count (Figure $3 \mathrm{~A})$.

$\mathrm{PCV}$ and $\mathrm{Hb}$ of $C$. gariepinus that fed the various garlic supplemented diets were significantly higher $(P<0.05)$ when compared to those fed the control diet. However, fishes in $0.5 \%$ concentration had higher PCV (ANOVA: $\mathrm{F}=295, P<0.001$ ) and $\mathrm{Hb}($ ANOVA: $\mathrm{F}=127, P<0.001)$ than those in the other concentrations (Figure $3 \mathrm{~B}$ and $4 \mathrm{~A})$.

No differences (ANOVA: $\mathrm{F}=2.6, P=0.06$ ) were observed in the plasma protein of fish fed the various experimental feeds. However, the volume of plasma protein in the $0.5 \%$ treatment group was higher compared to the plasma protein of fish in the control, $1 \%$ and $3 \%$ groups. 


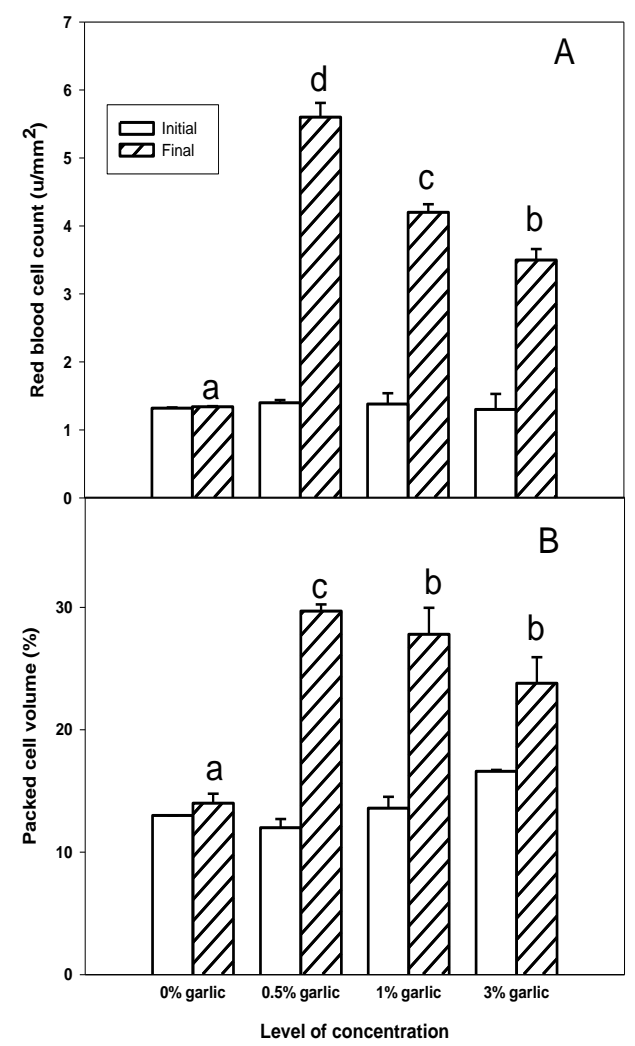

Figure 3. (A) Mean red blood cell count x1012 (B) Mean packed cell volume of Clarias gariepinus which fed four levels of garlic supplemented diet over 12 weeks period. The data represent mean \pm SE of three replicates per treatment group. Letters a, b, c and d represent a significant difference ( $p<0.05$, Tukey).

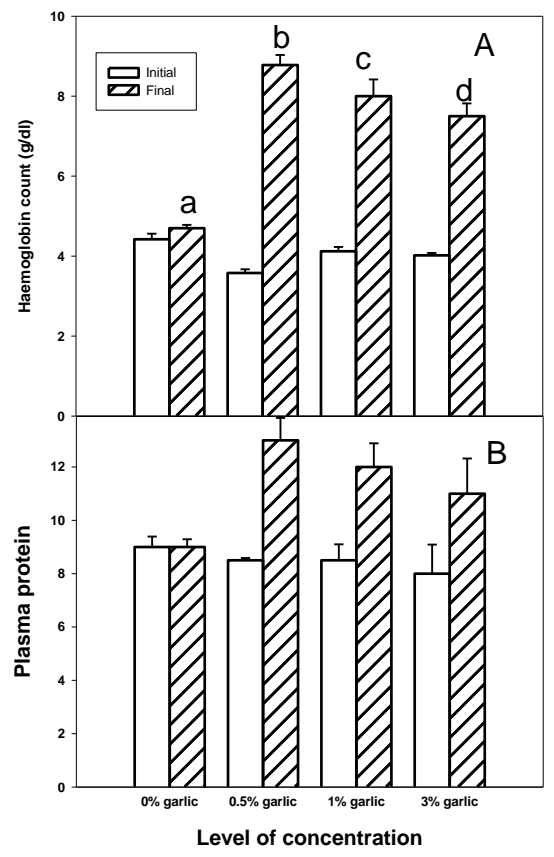

Figure 4. (A) Mean haemoglobin count (B) Mean plasma protein of Clarias gariepinus which fed four levels of garlic supplemented diet over 12 weeks period. The data represent mean \pm SE of three replicates per treatment group. Letters a, b, bc and c represent a significant difference $(\mathrm{p}<0.05$, Tukey) 


\section{Discussion}

The objective of this study was to investigate the growth and haematological response of Clarias gariepinus fingerlings to garlic supplemented diet. In order to achieve this, fish were fed with diets containing various concentrations of garlic for a period of twelve weeks. The diets were $0 \%$ garlic (control); $0.5 \%$ garlic; $1 \%$ garlic and $3 \%$ garlic. At the end of the experiment, no differences were observed in the weight gain of Clarias gariepinus fed the various experimental diets. However, fish fed garlic supplemented diet had a higher total length compared to fish in the control group. The similar weight gain among $C$. gariepinus in the various treatment groups shows that garlic at an inclusion rate of $0.5 \% ; 1 \%$ and $3 \%$ has no effect on the weight gain of $C$. gariepinus. This result is consistent with those of Ndong and Fall (2011) who observed that garlic inclusion in diets at a rate of $0.5 \mathrm{~g} / \mathrm{kg}$ did not result in a significant weight gain in juvenile hybrid tilapia (Oreochromis niloticus x Oreochromis aureus). However, Amin, Milad, Mohammad, Iraei, \& Morteza (2010) reported that garlic supplemented diet led to improved weight gain in rainbow trout (Oncorhynchus mykiss). This may be due to the higher rate of garlic in the diet compared to those used in this study. Increased weight gain has also been recorded by Dias et al. (2002) and Metwally (2009) for fish fed garlic supplemented diet.

WBC counts had a progressive weekly increase in fish fed the various garlic inclusions in diet with the exception of the control group. The improved WBC number observed in $C$. gariepinus fed the various garlic supplemented diets asserts the ability of garlic to improve immunological functions of fish blood. This finding concurs with Martins et al. (2002) who stated that garlic inclusion in diet is able to improve the WBC number of fish. Similarly, Ndong and Fall (2011) noted that the WBC count significantly increased in juvenile hybrid tilapia fed $0.5 \%$ garlic supplemented diet.

Likewise, red blood cell count, packed cell volume and haemoglobin level of fish fed the various levels of garlic supplemented diet was significantly greater than the control. This result agrees with Seeley, Stephens, and Tate (1992); Dias et al. (2002); Shalaby et al. (2006) and Lee and Gao (2012) who all stated that garlic increased the $\mathrm{RBC}$ count, $\mathrm{PCV}$ and $\mathrm{Hb}$ of fish.

Plasma protein was found to increase in all the garlic supplemented treatment groups but was however not significantly different from those of the control group which remained virtually unchanged. Increased levels of plasma protein have been recorded in fish fed with different concentrations of garlic in diets (Jha, Pal, Sahu, Kumar, \& Mukherjee, 2007; Nya \& Austin, 2009; Shalaby et al., 2006; Thanikachalam, Kasi, \& Rathinam, 2010).

\section{Conclusion}

This study shows that garlic supplemented diet yields more increase in total length and volume of haematological parameters of C. gariepinus. Garlic inclusion in fish diet is therefore of benefits in aquaculture.

\section{Acknowledgement}

The authors will like to appreciate Delta State University, Asaba Campus, Asaba for allowing the research to be conducted on their research farm.

\section{References}

Ahmadifar, E., Azari, T. G., \& Sudagar, M. (2009). Growth performance, survival and immunostimulation, of beluga (Huso huso) juvenile following dietary administration of alginic acid (Ergosan). Pakistan Journal of Nutrition, 8(3), 227-232. https://doi.org/htttp//doi.org/10.3923/pjn.2009.227.232

Amin, F., Milad, K., Mohammad, S., Iraei, M. S., \& Morteza, S. D. (2010). Effect of garlic (Allium sativum) on growth factors, some hematological parameters and body compositions in rainbow trout (Oncorhynchus mykiss). Aquaculture, Aquariu, Conservation \& Legislation; Cluj-Napoca, 3(4), 317-323.

Corzomartinez, M., Corzo, N., \& Villamiel, M. (2007). Biological properties of onions and garlic. Trends in Food Science \& Technology, 18(12), 609-625. https://doi.org/10.1016/j.tifs.2007.07.011

Dias, A. S., El-Nagar, G. O., \& El-Hady, Y. M. (2002). Evaluation of Nigella sativa (black seed, baraka), Allium sativum (garlic) and BIOGEN as feed additives on growth performance and immunostimulants of Oreochromis niloticus fingerlings. Suez Canal Veterinary Medical Journal, 1, 745-750.

FAO/WHO/OIE. (2006). Expect consultation on antimicrobials in use in aquaculture and antimicrobial resistance (pp. 13-16). Seoul Republic of South Korea.

Fazlolahzadeh, F., Keramati, K., Nazifi, S., Shirian, S., \& Sefi, S. (2011). Effect of garlic (Allium sativum) on hematological parameters and plasma activities of ALT and AST of Rainbow trout in temperature stress. 
Australian Journal of Basic Applied Science, 5(9), 84-90.

Harris, J. C., Cottrell, S. L., Plummer, S., \& Lloyd, D. (2001). Antimicrobial properties of Allium sativum (garlic) . Applied Microbiology and Biotechnology, 57, 282-286. http://dx.doi.org/10.1007/s002530100722

Jha, A. K., Pal, A. K., Sahu, N. P., Kumar, S., \& Mukherjee, S. C. (2007). Haematoimmunological responses to dietary yeast RNA, w-3 fatty acid and $\beta$-carotene in Catla catla juveniles. Fish Shellfish Immunology, 23, 917-927. https://doi.org/10.1016/j.fsi.2007.01.011

Lee, J., \& Gao, Y. (2012). Review of the Application of Garlic, Allium sativum, in Aquaculture. Journal of the World Aquaculture Society, 43(4), 447-458. https://doi.org/10.1111/j.1749-7345.2012.00581.x

Martins, M. L., Moraes, D. M., Miyazakii, C. D., Brum, E. M., Onaka, J., Fenerick, J., \& Bozzo, F. R. (2002). Alternative treatment for Anacanthorus penilabiatus (Monogenea: Dactylogyridae) infection in cultivated pacu, Piaractus mesopotamicus (Osteichthyes: Characidae) in Brazil and its haematological effects. Parasite, 9, 175-180. https://doi.org/10.1051/parasite/2002092175

Metwally, M. A. A. (2009). Effects of garlic on some antioxidant activities in Tilapia nilotica. World Journal of Fish and Marine Sciences, 1, 56-64.

Ndong, D., \& Fall, J. (2011). The effect of garlic (Allium sativum) on growth and immune responses of hybrid tilapia (Oreochromis niloticus $\mathrm{x}$ Oreochromis aureus). Journal of Clinical Immunology and Immunopathology Research, 3(1), 1-9.

Nya, E. J., \& Austin, B. (2009). Use of garlic, Allium sativum, to control Aeromonas hydrophila infection in rainbow trout, Oncorhynchus mykiss (Walbaum). Journal of Fish Diseases, 32, 963-970. https://doi.org/10.1111/j.1365-2761.2009.01100.x

Raa, L. G., Rodstand, G., Engstad, R., \& Robertson, B. (1992). The use of immunostimulant to increase resistance of Aquatic organisms to microbial infections. In M. Shari, R. P. Suasinghe, \& J. R. Authur (Eds.), Disease in Asian Aquaculture (Vol. 1, pp. 26-29). Manila, Philippines. http://dx.doi.org/10.1080/10641269609388587

Seeley, R. R., Stephens, T. D., \& Tate, P. (1992). Anatomy and Physiology. SRAC Publication, No 473, 1-3.

Shalaby, A. M., Khattab, Y. A., \& Abdel Rahman, A. M. (2006). Effects of Garlic (Allium sativum) and chloramphenicol on growth performance, physiological parameters and survival of Nile tilapia (Oreochromis niloticus). Journal of Venomous Animals and Toxins Including Tropical Diseases, 12(2), 172-201. http://dx.doi.org/10.1590/S1678-91992006000200003

Subasinghe, R. (1997). Fish health and Quarantine. In A Review of the state of the world Aquaculture, FAO Fisheries circular NO. 886. Food and Agricultural Organization of the United Nations. Rome, Italy.

Thanikachalam, K., Kasi, M., \& Rathinam, X. (2010). Effect of garlic peel on growth, hematological parameters and disease resistance against Aeromonas hydrophila in African catfish Clarias gariepinus (Bloch) fingerlings. Asian Pacific Journal of Tropical Medicine, 614-618. https://doi.org/10.1016/S1995-7645(10)60149-6

Yunxia, A. S., Jianzhong, S., \& Guoliang, W. (2001). A review of principal bacterial disease of mariculture fish. Transactions of Oceanology and Limnology, 2, 78-87.

\section{Copyrights}

Copyright for this article is retained by the author(s), with first publication rights granted to the journal.

This is an open-access article distributed under the terms and conditions of the Creative Commons Attribution license (http://creativecommons.org/licenses/by/3.0/). 